\title{
EDUCAÇÃO E TECNOLOGIA: A REAFIRMAÇÃO DO ENSINO TRADICIONAL NAS INOVAÇÕES TECNOLÓGICAS
}

\author{
Manoel Dionizio Neto ${ }^{1}$
}

\begin{abstract}
Resumo
Tem-se aqui o propósito de pensar a educação em meio à tecnologia, com ênfase ao que está posto como ensino remoto, considerando-se para isto a significação dessa modalidade de ensino em relação à crítica à educação tradicional. Neste sentido, parte-se das noções fundamentais do que se consolidou historicamente como educação tradicional, objeto de crítica, sobretudo a partir do século XVIII, e ao mesmo tempo base para diferentes modalidades de ensino que, por sua vez, alimentam características essenciais que lhe são próprias. Destaca-se como exemplo disso o tecnicismo. E, com vistas a este tecnicismo, faz-se possível a crítica à tecnologia e à inovação da educação tradicional, permitindo-se, pois, falar da educação a distância como uma nova forma de se pôr ou de se impor a educação tradicional expressamente criticada por diferentes estudiosos da educação em suas diferentes perspectivas. Toma-se, então, a Teoria Crítica, convencionalmente também conhecida como Filosofia da Escola de Frankfurt como referencial para se pensar a significação dessa nova modalidade de ensino como inovação da educação tradicional amplamente criticada. Assim, tomando-se por referência o que caracteriza a educação tradicional, conforme o exposto por autores como Snyders, Not, Saviani e Libânio, entre outros, concluise que o ensino tradicional, agora em sua versão inovada pelas mais avançadas tecnologias, tendo como base as Tecnologias da Informação e Comunicação (TIC), é um recurso indispensável à sustentação do modelo capitalista de dominação no âmbito da economia e, portanto, da política, razão pela qual recorre-se a essa modalidade de ensino na sua forma mais disfarçada de ser, o que parecia não ter mais lugar na sociedade contemporânea em termos de educação.
\end{abstract}

Palavras-chave: Educação Tradicional, Tecnologia, Educação a Distância, Ensino Remoto, Teoria Crítica.

\section{EDUCATION AND TECHNOLOGY: A REAFFIRMATION OF TRADITIONAL TEACHING IN TECHNOLOGICAL INNOVATIONS}

\begin{abstract}
The purpose here is to think about education in the midst of technology, with emphasis on what is known as remote teaching, considering the significance of this teaching modality in relation to the criticism of traditional education. In this sense, it starts from the fundamental notions of what has historically been consolidated as traditional education, object of criticism, especially since 18th century, and at the same time the basis for different teaching modalities that, in turn, feed essential characteristics that are their own. Technicism stands out as an example for that. Analysing technicism, it is possible to criticize technology and innovation of traditional education, allowing, therefore, to speak of distance education as a new way of putting or imposing the traditional education expressly criticized by different education scholars in their different perspectives. Critical Theory, also known as Philosophy of the Frankfurt School, is taken as reference to think about the significance of this new teaching modality as an innovation of the widely criticized traditional education. Taking as reference what defines traditional education, as exposed by authors such as Snyders, Not, Saviani and Libânio, among others, it follows that traditional education, now in its innovative version by the most advanced technologies, based on Information and Communication Technologies (ICT), is an indispensable resource for sustaining the capitalist model of domination within the economy scope and, therefore, of politics, which is why this type of teaching is used in a more disguised form, being what seemed to have no place in contemporary society in terms of education.
\end{abstract}

Keywords: Traditional Education, Technology, Distance Education, Remote Teaching, Critical Theory.

1 Graduado em Filosofia pela UFPE (Licenciatura e Bacharelado), Mestrado em Filosofia pela UFPB e Doutorado em Educação pela UFSCar, Professor Associado IV, lotado na UACS/CFP/UFCG. Atua como professor de Filosofia e tem realizado estudos sobre educação, escola, arte, ética, espaço, tempo, corpo, gestão escolar e a questão de gênero, tendo como referência Rousseau, Kant e a Teoria Crítica, com ênfase em Marcuse, Adorno e Horkheimer, bem como o existencialismo e a fenomenologia, ressaltando-se Sartre e Merleau-Ponty. Contato: dionizioneto@uol.com.br ou manoel.dionizio@professor.ufcg.edu.br. 


\section{Introdução}

Em 1750, Jean-Jacques Rousseau ganhara o prêmio da Academia de Dijon, convicto de que seria necessário examinar a questão proposta por ela: se teria havido ou não aprimoramento dos costumes pelas ciências e as artes. E com vista a sua resposta negativa, afirmara: "Não é em absoluto a ciência que maltrato, disse a mim mesmo, é a virtude que defendo perante homens virtuosos" (ROUSSEAU, 1999, p. 185). Portanto, ao mesmo tempo em que afirmava que as ciências e as artes não tinham contribuído para o melhoramento dos costumes, dizia não estar maltratando a ciência por pensar assim. Hoje, quando relacionamos a tecnologia às grandes conquistas da humanidade, faz-se igualmente necessário perguntar pelos reais benefícios que ela trouxe à própria humanidade. É, portanto, com esta questão que perguntamos pela significação da tecnologia para a educação ao tempo em que somos levados a abraçá-la como instrumento que facilita o ensino-aprendizagem.

Não é, pois, nosso propósito aqui adentrar no pensamento de Rousseau para pensar a questão da ciência, e também das artes, compreendidas estas no âmbito da compreensão grega para o que, hoje, reconhecemos como tecnologia, mas tomar para a nossa reflexão o sentido da tecnologia para a educação, bem como de toda projeção dessa educação promovida pela tecnologia. Assim, à semelhança do que afirmara Rousseau no século XVIII, não se trata de maltratar a tecnologia, mas de pensar na dignidade humana que pode estar ou não violentada pelos rumos que foram dados às inovações tecnológicas. É neste sentido que perguntamos pela educação, considerando as diferentes formas com que ela tem se estabelecido entre os homens e as mulheres que formam a humanidade inteira. Certamente falamos aqui de forma mais específica da educação formal, mediada pela escola, como lugar em que se faz o ensino com vistas a fins peculiares a determinadas formações que requerem para esses homens e mulheres em meio à sociedade que vem se fazendo historicamente conforme à diversidade de interesses de que se valem as pessoas para darem um norte à condição humana de existência.

Assim, é tendo em vista às diferentes tendências do ensino, que perguntamos pela tecnologia que tem sido posta a serviço da educação escolar. Neste sentido, é em meio às tendências do ensino, que se encontra o ensino tradicional ou nas suas diferentes inovações como ensino humanista, comportamentalista, tecnicista, cognitiva ou sociocultural, como são referidas por Maria da Graça Nicoletti Mizukami. Em linhas gerais, segundo, José Carlos Libâneo, há duas tendências da pedagogia: a liberal e a progressista. A primeira, por sua vez, representadas pelas tendências liberal tradicional, renovada progressivista e liberal tecnicista,

\begin{tabular}{|l|l|l|l|l|}
\hline Qevista Oialectus & Ano 9 & n. 19 & Agosto - Dezembro 2020 & p. 197-224 \\
\hline
\end{tabular}


por um lado, e, por outro, a progressista libertadora, a progressista libertária e a "crítico-social dos conteúdos". Considerando essas tendências, ou intencionalidades da educação, ao pensarmos na tecnologia na educação, perguntamos pelo modo de inserção dessa tecnologia no processo ensino-aprendizagem conforme às suas diferentes abordagens. Com vistas nisto, e considerando o que se propõe hoje como inovação tecnológica na escola, convém perguntar pelo modo de ensinar e de aprender promovido pelas inovações tecnológicas.

Orientando nossa reflexão sobre a educação a partir dessas referências - de um lado, as diferentes vertentes do ensino; por outro, a inserção das inovações tecnológicas na educação escolar, somo levados a pensar na forma tradicional de ensino que se renova cada vez que se implementa na escola uma inovação da tecnologia. Por isso não é nosso propósito aqui discorrer sobre as diferentes tendências da educação, seja seguindo, por exemplo, Mizukami ou Libânio, mas refletir a partir de alguns referenciais para situarmos a tendência da educação contemporânea impulsionada pela tecnologia que, graças ao advento da informática e da internet, possibilita diferentes atividades remotas, estando entre estas as do ensino. Portanto, não podemos perder de vista o exposto por Georges Snyders (1917-2011) e Louis Not (9192006), ao tempo em que recorremos à Teoria Crítica, onde buscamos elementos fundantes para pensar criticamente a significação da tecnologia para a educação.

\section{Noções sobre a educação tradicional}

É possível afirmar que, dentre todas tendências da educação, a mais conhecida, e também a mais combatida, seja a tradicional. Porém, ao mesmo tempo podemos afirmar que se trata daquela mais difícil de se discorrer a partir de determinados princípios ou conceitos postos em sua forma mais geral e sistemática. Isto porque não existe uma teoria que a exponha, delineando princípios norteadores ao ensino-aprendizagem que possam ser contestados e, portanto, rejeitados ao serem defendidos por teóricos da educação como base para o que se conhece como educação tradicional. Assim sendo, perguntamos pelo que pode (ou deve) ser o ensino tradicional. Trata-se, pois, de um termo que, conforme a observação de Georges Snyders vem carregado de "extrema ambiguidade": ao mesmo tempo que designa um modo de educação, com que ele se identifica, em sua quase totalidade e de forma indiferenciada, estagnações e erros, sejam oriundos das deficiências da formação de muitos professores ou que possam estar relacionadas "à inadaptação dos edifícios escolares, não excluindo esses

\begin{tabular}{|l|l|l|l|l|}
\hline Qenista Dialectus & Ano 9 & n. 19 & Agosto - Dezembro 2020 & p. $197-224$ \\
\hline
\end{tabular}


regulamentos antiquados que se mantêm precisamente porque os locais não permitem fazer melhor" (SNYDERS, 1974, p. 13).

À parte toda crítica que se faz a esse modelo de ensino, enfatizada com o advento da modernidade e sistematicamente formulada pelos iluministas franceses do século XVIII, culminou com a passagem da pedagogia às ciências da educação, consolidada no decorrer da segunda metade do século XX, completando-se e impondo-se mundialmente em sua transformação radical que se fez notar pela redefinição de sua identidade e renovação dos seus limites, ao tempo em que deslocou o seu eixo epistemológico: "Da pedagogia passou-se à ciência da educação; de um saber unitário e 'fechado' passou-se a um saber plural e aberto; do primado da filosofia passou-se ao das ciências", conforme observa Franco Cambi (1999, p. 595). Assim, nesses termos, Cambi nos coloca diante da revolução que ocorrera no âmbito da pedagogia que, abrindo-se e se fazendo plural, firmou-se nas ciências da educação que colocaram no cenário do ensino-aprendizagem outros modelos de ensino contrapostos ao que se conhece como educação tradicional.

Seguindo com esse olhar de Cambi a respeito dos modelos de ensino que surgiram com a passagem da pedagogia às ciências da educação, pode-se atentar para a discussão em torno da marginalidade, em nome da qual procurou-se teorizar sobre o ensino, firmando-se como teorias educacionais que, segundo Dermeval Saviani (1999, p. 15), classificam-se em dois grupos: "Num primeiro grupo, temos aquelas teorias que entendem ser a educação um instrumento de equalização social, portanto, de superação da marginalidade". Trata-se aqui, segundo ele, das teorias não-críticas. "Num segundo grupo, estão as teorias que entendem ser a educação um instrumento de discriminação social, logo, um fator de marginalização”, diz ele (Ibidem). Neste segundo grupo, de acordo com este entendimento de Saviani, encontram-se as teorias crítico-reprodutivistas. No primeiro caso, pode-se falar, conforme este mesmo autor, de teorias que perpassam por uma certa ingenuidade, acabando por reafirmar a educação tradicional para qual são apresentadas teorias alternativas, a exemplo da "Pedagogia Escola Nova" e da "Pedagogia Tecnicista". Por outro lado, no segundo caso, apesar de partirem da crítica à educação tradicional, contrapondo a ela novas alternativas: a "teoria do sistema de ensino enquanto violência simbólica", “a "teoria da escola enquanto aparelho ideológico de Estado (AlE)" e a "teoria da escola dualista'" (SAVIANI, 1999, p. 28), acabam não alterando o que tem sido desenvolvido pela educação tradicional, uma vez que não se trata de propostas pedagógicas que tenham em vista a substituição do modelo de ensino historicamente implementado nas escolas, conforme observação do próprio Saviani (1999, p. 40): "Na verdade

\begin{tabular}{|l|l|l|l|l|}
\hline Qenista Dialectus & Ano 9 & n. 19 & Agosto-Dezembro 2020 & p. $197-224$ \\
\hline
\end{tabular}


estas teorias não contêm uma "proposta pedagógica. Elas se empenham tão-somente em explicar o mecanismo de funcionamento da escola tal como está constituída”. Daí é possível compreender que "estas teorias consideram que a escola não poderia ser diferente do que é" (Ibidem).

Voltando-se, pois, para o primeiro desses grupos, Saviani identifica as teorias nãocríticas com a educação tradicional. Ao se colocarem de forma ingênua em relação à marginalidade, ignorando o contexto social, político e econômico em que ela se encontra, apresentam alternativas que, sejam priorizando os aspectos individuais como determinantes para a marginalidade, sejam focando o domínio dos recursos técnicos-científicos no exercício da docência, apresentam soluções para o problema da marginalidade que, por sua vez, seja em qualquer desses casos, parece ser determinado por fatores não relacionados ao meio sociocultural e econômico em que estão inseridas as pessoas que fracassam no processo ensinoaprendizagem, quando não são excluídas dele antes mesmo de terem qualquer acesso ao processo. Assim sendo, a partir do momento em que os professores selecionam e organizam os conteúdos a serem ministrados, também escolhem técnicas para o ensino e avaliação, refletindo nessas escolhas uma concepção de homem e de sociedade. Com vistas nisso, elaboram ou recorrem a teorias que fundamentam a sua prática pedagógica. Mas, não existindo teorias que exponham de uma forma sistemática o que seja educação tradicional, é a partir daquilo que consideram inviável ao ensino-aprendizagem na prática docente há muito conhecida, que seguem as tendências que, por sua vez, desprovidas de qualquer crítica às condições de inclusão ou de marginalização da escola, dão continuidade a um modo de educação que apenas ganha novos perfis sem deixar de sê-lo em sua essência. Assim ocorre com a denominada "Pedagogia liberal" que, segundo Libânio (1989), pode ser compreendida como "Tendência liberal tradicional", "Tendência liberal renovada progressista", "Tendência liberal renovada nãodiretiva" e "Tendência liberal tecnicista".

Não sendo aqui o nosso propósito discorrer sobre todas essas tendências, mas pensando no que pode levar ao entendimento de que, mesmo aparecendo como alternativas à educação tradicional, muitas vezes não passam de novas reformulações dessa modalidade de ensino, fica a questão a saber do que se trata quando falamos de educação tradicional. Mizukami, procurando caracterizr este modo de ensino, começa por ratificar o que estamos dizendo com outras palavras, ao afirmar que se trata de "uma abordagem do processo ensinoaprendizagem que não se fundamenta implícita ou explicitamente em teorias empiricamente validadas, mas numa prática educativa e na sua transmissão através dos anos" (MIZUKAMI,

\begin{tabular}{|l|c|c|c|c|}
\hline Qevista Dialectus & Ano 9 & n. 19 & Agosto-Dezembro 2020 & p. 197-224 \\
\hline
\end{tabular}


1986, p. 7). Essa mesma autora chama a atenção para o fato de se tratar de "uma concepção e de uma prática" de educação que, além de virem persistindo no tempo, têm fornecido "um quadro referencial para todas as demais abordagens que a ela se seguiram" (Ibidem). Isto ratifica o entendimento de Saviani, conforme fizemos saber aqui.

O ensino tradicional, diz Snyders, é um verdadeiro ensino. Esta não seria a primeira e grande razão para que tenha influenciado diferentes teorias educacionais como o referido por Mizukami? Pois, tomando as realizações da humanidade como modelos, e colocando o professor como mediador entre esses modelos e os alunos, normalmente crianças como adultos em formação, tem-se por fim proporcionar a alegria dessas crianças, que se aproximam desses modelos que têm os professores como seus representantes. A escola passa a ser o mundo onde se encontram esses modelos, que nada mais são que as grandes realizações humanas postas como referências à imitação por parte das crianças. Assim, as atividades postas pelo professor são tomadas como exercício de imitação de modelos para os quais deve estar voltada a atenção do aluno para que deles se aproxime cada vez mais. Tomando essas grandes realizações como exemplos, o aluno certamente se esforçará para segui-los. Sejam estes exemplos modelares expressos como grandes realizações no campo da ciência ou da arte, o aluno buscará autonomia para imitá-los. E isso não se fará sem o acesso a essas realizações, o que se fará como a aquisição de conhecimento. Por isso o castigo também se faz necessário quando falta a devida atenção a esses modelos a serem seguidos. Assim sendo, segundo Snyders, não há nenhum exagero na defesa do "fundamento da educação tradicional, isto é, na pretensão de conduzir o aluno até ao contacto com as grandes realizações da humanidade: obras primas da literatura e da arte, raciocínios e demonstrações plenamente elaborados, aquisições científicas atingidas pelos métodos mais seguros" (SNYDERS, 1974, p. 16).

Isso que, em síntese, é exposto por Snyders é o que está proposto por teóricos da educação, sejam no âmbito das ciências da educação ou da filosofia, mesmo sem nunca afirmarem categoricamente que estão defendendo essa forma de ensino. Isto é: apesar de não falarem em nome da educação tradicional, todos eles acabam convergindo, de um modo ou de outro, para isso que Snyders e outros apresentam como sendo próprio da educação tradicional. Exemplos deles são David Émile Durkheim (1858-1917), Émile-Auguste Chartier, conhecido pelo pseudônimo Alain (1868-1951), e Jean Yves Eugène Armand Alexis Château (19081990). Pois, como diz o próprio Snyders, não se desconhecendo, as suas diferenças terão que ser lembradas: "Para compreender as ambições essenciais da educação tradicional, como ela pode ser concebida e executada no nosso tempo, não nos parece descabido recorrer

\begin{tabular}{|l|l|l|l|l|}
\hline Qenista Dialectus & Ano 9 & n. 19 & Agosto-Dezembro 2020 & p. $197-224$ \\
\hline
\end{tabular}


simultaneamente [...] a três pedagogias a de Durkheim, a de Alain, a de Château" (SNYDERS, 1974, p. 16).

L. Not (1981), que conhece muito bem a obra de Snyders, concorda que esses três autores são indispensáveis como referências para se falar da educação tradicional. Assim, em sua obra As pedagogias do conhecimento, discorre sobre o que eles dispuseram para o ensino, e se refere a três significados que pode ter a palavra "tradicional" conforme sejam o método, o conteúdo e a origem do conhecimento pressuposto no ensinar e aprender. O primeiro deles, diz respeito ao método com vistas ao processo de ensino-aprendizagem sendo identificado pela letra T, por se tratar da transmissão do conhecimento, ao passo que, com a letra A, designa a origem tendo em vista os materiais mais antigos do patrimônio cultural. Pois, quando referida a esse patrimônio, a palavra tradicional se identifica com o $\mathrm{P}$, referindo-se ao conteúdo relacionado como as obras do passado que constituem esse patrimônio cultural. E, segundo o referido autor, a "transmissão dos conteúdos" é o que há de mais arcaico e também de mais simples para a pedagogia do conhecimento, pois, antes de tudo, funda-se na ideia de transmissão do "saber daquele que sabe para aquele que ignora; assim se organiza um sistema de relações entre o saber e as pessoas" (NOT, 1981, p. 26). Portanto, ao analisar a estrutura do processo educativo conforme este entendimento, ele esquematizou essa situação da seguinte forma: "uma pessoa $\mathrm{P}$ (que exerce uma função pedagógica) se propõe a transmitir um objeto de conhecimento O (noção, valor, processo de pensamento ou de ação, etc.) a um aluno A". Ele observa, então que há nisto duas relações: "uma da pessoa $\mathrm{P}$ à pessoa $\mathrm{A}$ e uma da pessoa $\mathrm{A}$ ao objeto O" (Ibidem).

Não vamos também discorrer sobre isso, pois nosso propósito é pensar, em linhas gerais, o que pode e que tem sido a educação tradicional, mas não podemos ignorar o que Not nos disse a respeito da funcionalidade dessa modalidade de ensino. Ele atenta para o fato de que a educação, para a pedagogia clássica, se faz pelas transformações dos alunos que, vistas como "conseqüência de uma longa série de impressões depositadas em seu espírito, seu papel é praticamente passivo durante a fase do ensino; só se torna ativo nas fases de execução ou de aplicação que podem, aliás, estar estreitamente associadas à fase de ensino" (NOT, 1981, p. 27). Isto significa dizer que, para a educação tradicional, "a linguagem é geradora de imagens, que segundo se espera, ficam impressas nas estruturas mentais do aluno". Assim sendo, devese observar o seguinte: “O verbo do professor, oral ou escrito, principalmente nos livros, será o produtor essencial dessas impressões”. E, quando se fizer necessário, deve-se duplicar a evocação verbal do professor "pela representação de objetos reais ou pela representação gráfica

\begin{tabular}{|l|l|l|l|l|}
\hline Qevista Dialectus & Ano 9 & n. 19 & Agosto-Dezembro 2020 & p. $197-224$ \\
\hline
\end{tabular}


cuja percepção deveria, acredita-se, preparar ou reforçar as impressões deixadas pela linguagem". Se isso ainda não for suficiente para que fiquem depositadas as impressões na mente dos alunos, que se veja também a possiblidade de se utilizar "a afetividade para avivar as impressões" (Ibidem).

Vemos, assim, como se pode entender a intermediação do professor em relação aos modelos referidos por Snyders e que estão devidamente ressaltados pelos autores a que ele se refere, sendo também referidos por Not: Durkheim, Alain e Château, cada um de acordo com o que pensa a necessidade de aproximação do aluno aos modelos a serem seguidos. Durkheim, segundo Not (1981, p. 40), tem como referência “a transmissão dos conteúdos culturais". Para ele "a sociedade domina o indivíduo: este está para sociedade como a célula está para um organismo vivo de estrutura complexa”. Isto significa que a felicidade do homem está condicionada à sua adaptação às normas que a sociedade lhe impõe: "O homem só pode ser feliz numa sociedade que lhe impõe normas e obrigações". Assim sendo, "Cada sociedade constrói o modelo de que necessita para cada fase do seu desenvolvimento”. Daí a necessidade da educação que, para Durkheim, é "a ação que as gerações adultas exercem sobre aquelas que não o são, para formá-las para a vida social” (Ibidem). Portanto, observa Not (1981, p. 41): “É preciso realizar o homem não como o fez a natureza, mas tal qual a sociedade quer que ele seja".

De algum modo, Alain e Château dão continuidade a esse modelo de ensino proposto por Durkheim, porém focando mais as obras do que a sociedade. Ou seja, para ele, a conquista do conhecimento se realiza nas obras. Quanto a isso, observa Not (1981, p. 45): "No centro de seu sistema, Durkheim coloca a sociedade como dado primeiro e valor supremo; no centro do seu, e sempre como dado primeiro e valor supremo, Alain coloca o homem”. Assim, é preciso considerar o seguinte: “A humanização do ser se faz graças ao tecido humano que está revestido; no plano cultural, são as obras que constituem este tecido, contudo elas não agem sobre um ser passivo" (Ibidem, p. 46), pois não se pode negar o fato de ser o homem composto pela razão e a liberdade. Mas Alain não perde de vista a importância do modelo que deve ser reconhecido pelo aluno como exemplo a seguir. Assim, diz Not (Ibidem, p. 55): "Três palavras bastam para definir o papel do mestre na pedagogia de Alain: é um modelo, um animador e um guia".

Château, por sua vez, entende que a educação não deve ser compreendida como se fosse uma facilitação para o crescimento da planta que se encontra "pré-formada na semente". Neste sentido, conforme as palavras de Not (1981, p. 56), trata-se da criação de um homem

\begin{tabular}{|l|l|l|l|l|}
\hline Qevista Dialectus & Ano 9 & n. 19 & Agosto-Dezembro 2020 & p. 197-224 \\
\hline
\end{tabular}


com um ser artificial: "É criar um ser artificial que de modo algum está esboçado na constituição genética. É criar um homem. Para isso é preciso que as diversas funções superiores sejam exploradas, desenvolvidas e dirigidas". Daí a necessidade de afastar-se do real para compreendê-lo, ou seja, incialmente, é preciso "dar-lhes as costas", conforme as palavras do próprio Château. Isto é: "É preciso ir às ideias, distanciar-se das situações [...]" (CHÂTEAU apud NOT, 1981, p. 57). Portanto, faz-se necessário mirar-se nos modelos, sendo os professores exemplos deles, como observa Not (1981, p. 57): "Assim também na perspectiva de J. Château, a educação se funda no 'contato com os mestres da civilização universal"”. Ou seja, como bem o disse Snyders (1974, p. 17-18): "Educar é propor modelos, escolher modelos, conferindo-lhes uma clareza, uma perfeição, em suma, um estilo que, através da realidade do dia a dia, não será possível atingir".

Por outro lado, Snyders nos chama a atenção para o que é comum na prática desse ensino que tem o modelo como referência: a ausência de conexão entre os modelos e a realidade vivida pelos alunos. Além disso, a desconfiança gerada pela família que passa a considerar ilusória a possibilidade de imitação que, por sua vez, leva os alunos aos constantes exercícios para alcançar essa imitação, gerando sofrimentos para os seus filhos, culmina muitas vezes na interferência da família na escola. Nisto está certamente um aceno ao fracasso do ensinoaprendizagem proporcionado pela educação tradicional. Daí, portanto, poder afirmar também o seguinte: "É evidente que a educação tradicional não dispensa a crítica, a avaliação crítica. E nós não hesitaremos em pô-la em prática" (SNYDERS, 1974, p. 49).

\section{Crítica à educação tradicional e ao tecnicismo}

Na "Introdução" à sua obra - As pedagogias do conhecimento -, L. Not (1981, p. 5) chama a atenção para o seguinte: "Desde o século XVIII, pelo menos, duas perspectivas pedagógicas se contrapõem. Numa quer-se ensinar, instruir, formar. Ensina-se uma matéria às crianças, ou seja, situa-se diante de dois objetos: a matéria e a criança; do exterior, modelado e equipado". Seguindo com este entendimento, este autor nos diz que, apesar de contrapostos, os métodos - antigo e moderno - são igualmente atuais. Não se trata, pois, de trocar o novo pelo velho, porque o novo se tornará tão velho quanto o que é mais antigo. Não se trata, assim, de confundir o antigo com o que é caduco. O novo se torna tradicional tanto quanto aquele que é considerado, hoje, tradicional.

\begin{tabular}{|l|l|l|l|l|}
\hline Qevista Dialectus & Ano 9 & n. 19 & Agosto-Dezembro 2020 & p. $197-224$ \\
\hline
\end{tabular}


Essa troca, pura e simples, do velho pelo novo tem sido o primeiro de todos os equívocos cometidos quando se trata de criticar a educação tradicional, propondo-se um método novo para o ensino-aprendizagem. Um outro equívoco que se pode encontrar quando se coloca a questão do método, segundo o mesmo autor, diz respeito à consideração do que é ou não atividade do processo de ensino e aprendizagem. Pois, segundo ele, a partir de Rousseau, a ação foi posta na origem de todo o conhecimento. Com isto, acaba-se multiplicando-se as atividades dos alunos, que passam a ser obrigado a executá-las, como se agindo de forma diferente, o aluno não fosse ativo, como ocorre com a aplicação do método tradicional ou antigo. Este entendimento de Not nos lembra a crítica feita por Saviani ao que ele chama "pedagogia nova". Pois, segundo ele, “a 'Escola Nova' organizou-se basicamente na forma de escolas experimentais ou como núcleos raros, muito bem equipados e circunscritos a pequenos grupos de elite" (SAVIANI, 1999, p. 21). Consequentemente, além da ampla difusão do seu ideário, este "penetrou nas cabeças dos educadores acabando por gerar consequências também nas amplas redes escolares oficiais organizadas na forma tradicional" (Ibidem, p. 21-22). Esbarrase assim, segundo Saviani (1999, p. 22), em um paradoxo: ao invés de resolver o problema da marginalidade deixado pela educação tradicional, “a 'Escola Nova' o agravou”.

Falamos assim da crítica ao modelo tradicional de ensino que deu lugar a novas formas de ensino e aprendizagem. E, se devemos falar do que ocorrera neste sentido, no século XVIII, o que é inevitável, podemos dar um passo atrás e certificarmo-nos de que a Reforma Protestante, ocorrida no início do século XVI, já passava por essa crítica, convertendo-se no modo de ser da educação conforme os princípios professados por Martin Lutero e, logo em seguida, ao que se passou a ter como modelo proposto pela Companhia de Jesus, no âmbito da Contrarreforma. Assim, é possível falar como Manacorda (2000, p. 193-194): “De fato, é agora que começa a se propor novamente o problema do como e quanto instruir, quem é destinado não tanto ao domínio, mas à produção". E, depois, este mesmo autor afirma o seguinte: "Tradicionalmente os movimentos populares heréticos promoveram difusão da instrução a fim de que cada um pudesse ler e interpretar pessoalmente a Bíblia, sem a mediação do clero" (Ibidem, p. 194). Isso culminou nas mais diferentes reformas por que passara a educação escolar refletidas nas diversas teorias pedagógicas. A propósito disto, podemos compreender o que nos diz o Pe. Leonel Franca S. J (1952, p. 5): "No desenvolvimento da educação moderna o Ratio Studiorum ou Plano de Estudos da Companhia de Jesus desempenha um papel cuja importância não é permitido desconhecer ou menosprezar".

\begin{tabular}{|l|l|l|l|l|}
\hline Qevista Dialectus & Ano 9 & n. 19 & Agosto - Dezembro 2020 & p. $197-224$ \\
\hline
\end{tabular}


Assim sendo, chegamos no século XVIII, quando essas reformas acabam ganhando um caráter revolucionário. O humanismo entra em crise com as grandes descobertas ocorridas no século XVII, e a necessidade de se repensar o ensino é cada vez maior. Podemos voltar ao exposto por Manacorda ao tratar dessa crise e do modo como fora encarada pelos iluministas. Tratava-se, segundo ele, de estender a educação a todos os homens, o que já tinha sido ressaltado por Jean Amos Comenius que, em sua Didáctica magna, pensa a educação como "arte universal de ensinar tudo a todos", como está posto no subtítulo, permitindo-lhe afirmar: "Que devem ser enviados às escolas não apenas os filhos dos ricos ou dos cidadãos principais, mas todos por igual, nobres e plebeus, ricos e pobres, rapazes e raparigas, em todas as cidades, aldeias e casais isolados [...]" (COMÉNIO, § 1, 1985, p. 139). Certificando-se, portanto, de que passou a ser objetivo da educação moderna estender a edcuação a todos os homens, podese afirmar o seguinte: “de várias maneiras, com diferentes iniciativas e não sem graves recaídas no paternalismo e no assistencialismo, os iluministas, os novos utopistas, os reformadores e os revolucionários deste século tentam concretizar este ideal” (MANACORDA, 2000, p. 236). Seguindo com este entendimento, Manacorda (2000, p. 242) ressalta o seguinte:

Sem dúvida, Rousseau revolucionou totalmente a abordagem da pedagogia, privilegiando a abordagem que chamarei "antropológica", isto é, focalizando o sujeito, a criança ou o homem, e dando um golpe feroz na abordagem "epistemológica"”, centrada na reclassificação do saber e na sua transmissão à criança como um todo já pronto. Pela primeira vez, ele enfrenta com clareza o problema, focalizando-o "do lado da criança", considerada não somente como homem in fieri, mas propriamente como criança, ser perfeito em si.

Essa revolução operada pelo pensamento de Rousseau influenciou certas teorias da educação, sendo a Escola Nova um exemplo disso, guardadas as substanciais diferenças. Mas, diante do fracasso dessa escola, ou da conversão do escolanovismo em uma nova modalidade de ensino tradicional, um novo ideário da educação se faz notar como uma espécie de "Escola Nova Popular", representada por Freinet e Paulo Freire, por outro lado, "radicalizava-se a preocupação com os métodos pedagógicos presentes no escolanovismo que acaba por desembocar na eficiência instrumental", conforme nos faz saber Saviani. Com isto, segundo ele, articulava-se "uma nova teoria educacional: a pedagogia tecnicista" (SAVIANI, 1999, p. 23), funcionando a escola, segundo Libânio (1989, p. 28), "como modeladora do comportamento humano, através de técnicas específicas". Assim sendo, ele acrescenta: "À educação escolar compete organizar o processo de aquisição de habilidades, atitudes e conhecimentos específicos, úteis e necessários para que os indivíduos se integrem na máquina

\begin{tabular}{|l|l|l|l|l|}
\hline Qevista Dialectus & Ano 9 & n. 19 & Agosto-Dezembro 2020 & p. $197-224$ \\
\hline
\end{tabular}


do sistema social global" (Ibidem, p. 28-29). Isto, segundo Saviani (1999, p. 23), assemelha-se ao que ocorreu com a passagem do trabalho artesanal para o trabalho fabril, objetivando-se o trabalho pedagógico: "Com efeito, se no artesanato o trabalho era subjetivo, isto é, os instrumentos de trabalho eram dispostos em função do trabalhador e este dispunha deles segundo seus desígnios, na produção fabril essa relação é invertida". Impõe-se com isso a adaptação do trabalhador ao processo de trabalho objetivado que, por sua vez, é também organizado em parcelas. Consequentemente, "o trabalhador ocupa seu posto na linha de montagem e executa determinada parcela do trabalho necessário para produzir determinados objetos. O produto é, pois, uma decorrência da forma como é organizado o processo”. Assim, de igual modo, espera-se a adaptação do professor ao processo ensino-aprendizagem objetivado pela técnica a que deve ser submetido para que se possa alcançar um resultado previamente esperado conforme a organização proposta para este processo segundo a instrumentalização técnica em tantas etapas quantas forem necessárias. O ensino-aprendizagem se faz, então, como produto, não passando o professor de mero condutor das técnicas mais apropriadas para os fins propostos.

Em que, pois, podemos ver a diferença entre essa forma de ensino e a forma tradicional de ensinar? E qual pode ser a diferença entre a pedagogia tecnicista e a pedagogia nova? Saviani (1999, p. 24) apresenta-nos de forma clara e objetiva essas diferenças:

\footnotetext{
Se na pedagogia tradicional a iniciativa cabia ao professor que era, ao mesmo tempo, o sujeito do processo, o elemento decisivo e decisório; se na pedagogia nova a inciativa desloca-se para o aluno, situando-se o nervo da ação educativa na relação professor-aluno, portanto, relação interpessoal, intersubjetiva - na pedagogia tecnicista, o elemento principal passa a ser a organização racional dos meios, ocupando professor e aluno posição secundária, relegados que são à condição de executores de um processo cuja concepção, planejamento, coordenação e controle ficam a cargo de especialistas supostamente habilitados, neutros, objetivos, imparciais. A organização do processo converte-se na garantia da eficiência, compensando e corrigindo as deficiências do professor e maximizando os efeitos de sua intervenção.
}

Observa-se, por outro lado, que, em nome de uma "neutralidade", camufla-se a continuidade da sobreposição de um agente externo no processo educativo. E isto se faz, disfarçadamente, pelo professor, não mais como mediador entre os modelos e os alunos, mas como intermediário entre os interesses determinantes para a difusão de um conteúdo que terá que ser absorvido pelos alunos conforme o domínio da técnica. Ou seja, como diz Not, a educação se fundamenta numa espécie de enxerto de produções externas que se destinam à formação do aluno. Trata-se aqui de hétero-estruturação. $\mathrm{O}$ aluno, portanto, se educa com a

\begin{tabular}{|l|l|l|l|l|}
\hline Qevista Oialectus & Ano 9 & n. 19 & Agosto-Dezembro 2020 & p. 197-224 \\
\hline
\end{tabular}


produções externas que são enxertadas nele por um agente também exterior: o educador, que não terá que ser necessariamente o professor. Mas os alunos são coagidos a absorver o conteúdo que lhes é oferecido, sem se darem conta disso, uma vez que tudo se faz mediado pela técnica sob a condução do professor, refletindo-se nisto o que é próprio dos métodos coativos que, por sua vez, são próprios à educação tradicional. "Os métodos coativos podem ser definidos como métodos de duplo sujeito, devido aos papéis que aí representam o aluno e o pedagogo: o primeiro executa uma ação que o outro dirige", diz Not (1981, p. 63). Os alunos, ao executarem determinadas técnicas a que têm acesso pela direção do professor, ficam convencidos de que são autônomos no processo ensino-aprendizagem, não se dando conta de que estão sob a direção do professor. Todavia, há nisto a atuação de um duplo sujeito: o que executa e o que dirige: “o aluno age, mas as iniciativas que regem sua atividade pertencem ao mestre e nessa situação ele se torna lugar de uma ação que o outro exerce sobre ele, para formá-lo, como se forma um objeto" (NOT, 19891, p. 63). Assim, continua Not, o aluno “é sujeito sujeitado, e esses métodos se inserem num projeto de hétero-estruturação do conhecimento, semelhante, nisso, àquele em que se incluem os métodos tradicionais".

É interessante lembrar que L. Not também teve o cuidado de pensar a questão dos métodos coativos no contexto das sociedades dos séculos XIX e XX. Quanto ao primeiro, ele afirma: "Desde a segunda metade do século XIX, as teorias de Darwin orientaram o interesse para a importância que as diferenças individuais adquirem nos processos de adaptação ao meio e, portanto, para as possibilidades de sobrevivência e expansão dos indivíduos”. Por outro lado, deve-se considerar a sociedade industrial que também se desenvolve nessa mesma época. $\mathrm{E}$, ao se desenvolver "em uma direção de livre concorrência, orienta-se conforme as mesmas preocupações das teorias de Darwin: "triunfo dos mais aptos e busca dos meios de aumentar as aptidões individuais adaptando os tratamentos pedagógicos aos recursos e às necessidades próprias a cada indivíduo" (NOT, 1981, p. 70). Isso valeu como estímulo para se pensar a necessidade do investimento nas técnicas também no âmbito pedagógico, tendo como consequência o desenvolvimento das novas tecnologias da educação. A propósito disto, diz Cambi (1999, p. 616):

Com as novas tecnologias educativas, operadas pelas pesquisas do neocomportamentalismo de Skinner e pelo desenvolvimento da computei science, veio se delineando uma centralidade sempre maior atribuída às máquinas nos processos de ensino e aprendizagem (não mais suportes, mas protagonistas do ensino): como a calculadora, o televisor, os vídeos, os computadores. Desse modo, transformou-se radicalmente o modo de aprender-ensinar: tornou-se mais impessoal, mais controlável, mais microestruturado, mais capaz de autocorreção (através do

\begin{tabular}{|c|c|c|c|c|}
\hline Rovista Dialectus & Ano 9 & n. 19 & Agosto - Dezembro 2020 & p. $197-224$ \\
\hline
\end{tabular}


feedback dos circuitos cibernéticos, que é um voltar atrás para modificar o próprio operado e obter resultados melhores).

É de se perguntar aqui sobre o que seria de significativo nesse ensinar e nesse aprender mediados pelas novas tecnologias. Vale considerar a importância que pode ser considerada no âmbito ideológico: o ensino-aprendizagem ganha uma reforça a mais para o seu caráter de neutralidade, expresso pela impessoalidade da tecnologia que avança em direção à informatização e à consequente popularização do computador. E Skinner advoga, segundo Cambi (1999, p. 616), que as diversas máquinas disponibilizadas para o ensino "são pedagogicamente positivas porque permitem a autocorreção, porque seguem o ritmo natural da aprendizagem, porque têm uma sequência coerente". Todavia, para Skinner, o aluno pode ser conduzido ao comportamento que se queira, por mais alta que seja sua complexidade. E assim “a aprendizagem só poderia ser uma construção sintética, organizada pelo pedagogo de acordo com a estrutura do comportamento que ele projeta para o aluno" (NOT, 1981, p. 76). Portanto, é preciso levar em consideração duas séries de problemas do sistema de educação que ele apresenta para o homem; "uma se refere à legitimidade e à validade da transferência, para o homem, das conclusões tiradas da observação de animais e dos processos efetuados com eles, a outra diz respeito às modalidades que o reforço implica para a organização da aprendizagem" (Ibidem).

Uma das primeiras observações que se pode fazer a respeito do significado desse sistema de educação proposto por Skinner é o que ficou conhecido como psicologismo, que passou a fundamentar a didática bastante adotada nas escolas que se opunham, ao mesmo tempo, ao ensino tradicional e à Nova Escola. Com vistas nisso, Maria Mercedes Capelo Alvite (1981, p. 61) chama a atenção para o prejuízo que se tem no âmbito da educação e, portanto, para a formação humana em termos gerais, esse psicologismo fundamentado no behaviorismo skinneriano, ao se referir à necessidade de superá-lo: "Para que se supere o psicologismo que ainda impera na escola, é imprescindível que se analise as várias tendências marcadamente psicológicas e individualistas da educação, entre as quais se encontra o behaviorismo". Certamente este não é o espaço para se fazer essa análise a que ela se refere, todavia não podemos ignorar algumas questões que nos permitem pensar sobre o significado da educação fundamentada no sistema de Skinner. Portanto, vale considerar, por exemplo, a afirmação que dela sobre a psicologia adotada por esse referido autor: "a psicologia [dada a influência do esquema behaviorista de estímulo-resposta] modela para o homem à imagem do homem autômato, da homem máquina, adequando-se perfeitamente à filosofia da sociedade comercial"

\begin{tabular}{|l|l|l|l|l|}
\hline Qevista Dialectus & Ano 9 & n. 19 & Agosto-Dezembro 2020 & p. 197-224 \\
\hline
\end{tabular}


(Ibidem, p. 62). Assim sendo, ainda segundo ela, para se falar das implicações da abordagem de Skinner para a educação, "tomou-se como ponto de partida sua convicção de que homem é um ser manipulável, uma criatura circunstancial, governada por estímulos fornecidos pela ambiente externo" (Ibidem, p. 64). É o que está dito com outras palavras pelo próprio Skinner (apud ALVITE, p. 64): "Uma análise experimental do comportamento humano deveria, por natureza, retirar as funções anteriormente atribuídas ao homem autônomo e transferi-las, uma a uma, ao ambiente controlador".

Entende-se, então, quando se diz, como o faz Maria Lúcia de Arruda Aranha (2010, p. 230), que as propostas pedagógicas inpiradas no tecniciscmo surgiram, a partir da década de 1960, “baseadas na convicção de que a escola só se tornaria eficaz se adotasse o modelo empresarial, ou seja, fosse aplicado na escola o modelo de racionalização típico do sistema de produção capitalista”. E isso se evidencia mais ainda quando a tecnologia ganha o caráter de informatização com o desenvolvimento da computação, fazendo-se, por sua vez, como Tecnologias da Informação e Comunicação (TIC). Agora, muito mais do que antes, é possível a afirmação, segundo a qual, a coisificação humana tem tomado a dimensão das máquinas a que servem essas tencologias, de modo que é preciso perguntar se os meios não se converteram em fins. Isto se configura de forma exemplar quando a educação se faz virtualmente, criando um distanciamente maior entre professor e aluno, ao tempo em que, contraditoriamente, encurta cada vez mais os espaços.

\section{A tecnologia e a inovação da educação tradicional}

De que forma podemos pensar numa inovação pedagógica advinda desse desenvolvimento tecnológico? Penso ser significativa a necessidade de se refletir a respeito do que afirmara Herbert Marcuse (1982, p. 23): “Uma falta de liberdade confortável, suave, razoável e democrática prevalece na civilização industrial desenvolvida, um testemunho do progresso técnico". É possível, sim, considerar o progresso técnico associado a uma demanda social, de forma que se possa, também, considerar as novas tecnologias que vão surgindo sejam indispensáveis a essa demanda, para que se possa contar com uma vida permeada pelo conforto de certa falta de liberdade. E, nesses termos, podemos considerar o que tudo isso significa para a educação. Face às demandas sociais, está o desenvolvimento tecnológico convidando professores e alunos a se reinventarem para que essas demandas possam ser atendidas. Com

\begin{tabular}{|l|l|l|l|l|}
\hline Qenista Dialectus & Ano 9 & n. 19 & Agosto-Dezembro 2020 & p. $197-224$ \\
\hline
\end{tabular}


vistas nisso, é possível compreender afirmações como a de Natal Lânia Roque Fernandes (2004, 17): "No dia-a-dia do professor, apresentam-se exigências ou necessidades que podem levá-lo a novas aprendizagens relacionadas ao exercício da docência". Pois bem: essas "novas aprendizagens" se conquistam, em nossa época, fazendo-se o uso das novas tecnologias disponibilizadas para a escola. E, se não podemos escapar dessa forma de aprender, sem o tempo disponível a perguntar pela sua razão de ser, não está nisto o conforto da falta de liberdade referida por Marcuse? Por isso ele pergunta:

De fato, o que poderia ser mais racional do que a suspensão da individualidade na mecanização de desempenhos socialmente necessários, mas penosos; a concentração de empreendimentos individuais em organizações mais eficazes e mais produtivas; a regulamentação da livre competição entre sujeitos econômicos desigualmente equipados; a redução de prerrogativas e soberanias nacionais que impedem a organização internacional dos recursos? (MARCUSE,1982, p. 23).

Certamente isso reflete a demanda social que requer a contínua aprendizagem referida por Natal Lânia Roque Fernandes. E ela nos chama ainda a atenção para o fato de que essas demandas são internas e externas. No primeiro caso, diz respeito às situações advindas do próprio cotidiano da sala de aula; no segundo, trata-se daquelas demandas "oriundas de ações sociais, econômicas e políticas na área de educação e que exigem do professor a mobilização de saberes próprios da profissão docente" (FERNANDES, 2004, p. 17). Em meio a isso, passa normalmente despercebido o fato de que temos de nos submeter a uma ordem tecnológica compreendida por "uma coordenação política e intelectual", mesmo que isso possa ser um "acontecimento lamentável, mas promissor", o que não deixa de ser racional (MARCUSE,1982, p. 23). Daí a necessidade de refletirmos sobre a significação das novas tecnologias, forjando-se com elas um mundo digital em que estamos imersos.

Aqui nos deparamos com todo investimento que se faz na razão instrumental, pois, graças à sua funcionalidade, as pessoas são convertidas à racionalidade que instrumentaliza os objetos com que temos que lidar para a produção requerida para uma sociedade do espetáculo e do consumo. Enquanto isso, cada vez mais vai ficando tolhida a razão emancipatória, aquela que se firma como crítica à razão que instrumentaliza seres humanos para atenderem os interesses empresariais. E isso ocorre quando homens e mulheres perdem sua autonomia em nome do autodidatismo, da autodisciplina, indispensáveis ao aprender a aprender requerido pela funcionalidade do modo de produção capitalista que vai se reatualizando segundo o progresso tecnológico. Com isto nos deparamos com a crise da formação cultural que, segundo Theodor

\begin{tabular}{|l|l|l|l|l|}
\hline Qenista Dialectus & Ano 9 & n. 19 & Agosto-Dezembro 2020 & p. $197-224$ \\
\hline
\end{tabular}


W. Adorno (2010c, p. 8), tem sido confundida com um simples objeto da pedagogia. Todavia, trata-se de um fato que também não pode ser restrito "a uma sociologia que apenas justaponha conhecimentos a respeito da formação". Ao invés disso, faz-se necessário observar o seguinte: "Os sintomas de colapso da formação cultural que se fazem observar por toda parte, mesmo no estrato das pessoas cultas, não se esgotam com as insuficiências do sistema e dos métodos da educação, sob a crítica de sucessivas gerações". E isto porque, segundo ele, "A formação cultural agora se converte em uma semiformação socializada, na onipresença do espírito alienado, que, segundo sua gênese e seu sentido, não antecede à formação cultural, mas a sucede. Desse modo, tudo fica aprisionado nas malhas da socialização" (ADORNO, 2010c, p. 9).

Voltamos, então, à significação do sistema de educação de Skinner para situarmonos em relação a essa semiformação referida por Adorno (2010c), o que se pode ver a partir daquilo que caracteriza os métodos coativos com vistas ao controle do comportamento, tomando-se como referência o comportamento animal. Isto é: Skinner parte da condição do animal para pensar na possibilidade de controle de todo organismo equivalente. Essa condição se faz pela relação estabelecida entre quem dirige e quem é dirigido, não sendo, por isso, a mesma significação dos atos "para o sujeito que dirige a atividade e para aquele que executa os atos" (NOT, 1981, p. 78). Com isto, segundo Not (1981, p. 80), opera-se uma verdadeira atomização da matéria a prender, de forma que os comportamentos são organizados, fazendose necessária a estrita ligação entre estímulo e resposta, ou seja, “entre o indutor e o induzido, pois são as perguntas que induzem às respostas, e a ordem na qual são apresentadas o que induz à estrutura do comportamento que se deseja criar". Assim sendo, segundo ele, há de se considerar o seguinte: “À rigidez dos comportamentos montados do exterior, elemento por elemento, segundo modelos pré-fabricados, não se pode deixar de opor a infinita riqueza das invenções ou das transformações, que a reflexão sugere sobre comportamentos organizados pessoalmente" (NOT, 1981, p. 81).

Creio que isso que nos é dito por Not seja o suficiente para se compreender a mecanização do ensino que se faz graças à utilização das TIC. Mas vale ainda chamar a atenção para o que ele diz sobre a relação do ensino com a máquina, à qual, na verdade, acabamos nos submetendo nesse processo de ensino e aprendizagem segundo às condições impostas pelas novas tecnologias: "São elas [as máquinas] que colocam o maior problema em todo projeto de mecanização do ensino: neste ponto chegou-se a progressos espetaculares, mas o problema ainda está longe de ser resolvido" (NOT, 1981, p. 108). E isto fica mais enfático nas palavras

\begin{tabular}{|l|l|l|l|l|}
\hline Qenista Dialectus & Ano 9 & n. 19 & Agosto-Dezembro 2020 & p. 197-224 \\
\hline
\end{tabular}


de Barbey (apud NOT, Nota 91, p. 108): “A máquina só pode encarregar-se dos 'saberes positivos' e da reflexão sobre esses saberes (...)". A isto acrescenta: "Assim, toda máquina aperfeiçoada está apta a ensinar a biografia de Karl Marx ou mesmo a discernir no marxismo as eventuais contradições lógicas ou falhas, enquanto máquina alguma, a nosso ver, pode discutir sua filosofia e sua concepção do mundo". Isto significa, tomando-se ainda as palavras deste autor citado por Not, que "A escolha, a decisão são coisas humanas", o que não se pode deixar sob o domínio da máquina. Ou seja: "Pode-se evidentemente imaginar máquinas que ensinariam o que se deve pensar da doutrina marxista; todavia, neste caso não estaríamos mais num contexto de formação e educação, mas logo num meio de deformação e deseducação" (BARBEY apud NOT, Nota 91, p. 108).

Mas sabemos nós do quanto é importante para os detentores dos meios de produção que o ensino se faça cada vez mecanizado, sendo isto expresso pelo que é referido como demandas externas. É o que está posto por Natal Lânia Roque Fernandes (2004, 2004, p. 18) quando se refere à realidade que precisa ser enfrentada pelo professor face às "novas exigências da sociedade contemporânea, decorrentes, dentre outros fatores, do desenvolvimento tecnológico em geral e na área de informática em particular, que vêm influenciando a construção e a socialização de várias áreas de conhecimento". De que conhecimentos, pois, se trata para que essas demandas sejam atendidas? Certamente todos os que se fazem imprescindíveis ao domínio das técnicas necessárias à informatização da escola. Pois o que a referida autora diz confirma este entendimento:

O desenvolvimento dessas competências exige a construção de conhecimentos que não fizeram usualmente parte do currículo de formação da maioria dos professores, tais como o conhecimento do conteúdo da informática, o de metodologias ou didáticas necessárias ao desenvolvimento desse conteúdo. Além disso, em seu trabalho com o computador poderão surgir situações pouco familiares aos professores, e que se referem a um maior domínio de conhecimento em informática também por parte do aluno. (FERNANDES, 2004, p. 18).

Certamente não se pode negar o fato: essa demanda existe e não podemos escapar dela. Pois, como observa a própria Fernandes (2004), a partir da década de 1970, aparece nas escolas brasileiras a preocupação com a inserção das novas tecnologias que, por sua vez, perpassavam necessariamente pela inclusão da informática no ensino em seus diferentes níveis, a começar pelo nível básico, requerendo-se, com isso, a adequação da formação de professores com vistas a essas inovações tecnológicas. Por outro lado, não devemos negar a importância do

\begin{tabular}{|l|c|c|c|c|}
\hline Qevista Dialectus & Ano 9 & n. 19 & Agosto - Dezembro 2020 & p. $197-224$ \\
\hline
\end{tabular}


domínio das técnicas, com as quais se pode avançar em relação ao domínio do espaço e do tempo, encurtando caminhos e melhorando as condições de vida das pessoas em geral. Mas o que não está dito, porém submerso em toda demanda da tecnologia, é o fato de que ela acaba expressando uma razão instrumental que, como já dissemos, está a serviço das grandes empresas e dos grandes negócios. Com outras palavras, a tecnologia avança, enfim, em direção à satisfação aos interesses do capital. Para isso, buscam-se diferentes artifícios de caráter ideológico, entre eles, mecanismos para um certo distanciamento entre as pessoas, tomando-se como exemplo para isso, a distância requerida na relação professor e alunos. Isto serve para o condicionamento a uma frieza que possa se estabelecer cada vez com mais intensidade nas relações humanas, sendo as pessoas modeladas como se fossem coisas entre coisas, ou peças de uma engrenagem maior como ferramentas que fazem parte de um aglomerado tecnológico representado pelas máquinas. Desse contexto formativo, fica excluído do ensino tudo que envolva a subjetividade, como sejam: a pintura, a poesia e as artes em geral e, sem dúvida, o ensino da filosofia. Pois, como diz Barbey (apud NOT, Nota 91, p. 108): “O ensino programado da filosofia parece-nos um contrassenso" (BARBEY apud NOT, Nota 91, p. 108).

Vemos assim que o advento da tecnologia, compreendido como estágio avançado do domínio técnico alcançado pela humanidade, tornou-se notório sobretudo depois da Segunda Guerra Mundial, como vemos expresso nas palavras de Manacorda (2000, p. 335): “Os fenômenos decisivos para a educação na segunda metade do século $[X X]$, após o trágico conflito mundial, são o progresso tecnológico e a maturação das consciências 'subalternas'. Esses fenômenos se evidenciam especialmente em dois momentos”. Esses momentos, segundo ele, se fizeram com o lançamento do sputnik soviético, bem como com a expansão da instrução, criando expectativas e desilusões nas novas gerações. Consequentemente, o mundo assistiu, em 1968, a revolta estudantil: "Em todo o mundo, 1968 foi o ano da revolta estudantil e juvenil, que explodiu mais violenta e clamorosa onde as forças políticas aparentemente mais inclinadas a críticas radicais e mudanças reais menos esperavam” (MANACORDA, 2000, p. 341). Os estudantes foram seguidos pelos operários, que passaram a reivindicar também direito à qualificação profissional em que passaram a ser atendidos segundo os interesses empresariais: "Em geral, essas concessões e iniciativas educativas respondiam aos interesses da empresa no sentido de ter operários mais capazes, mas ao mesmo tempo permitiam aos operários uma certa mobilidade (horizontal e vertical) no interior da fábrica" (Ibidem, p. 342). E para que se façam atendidos esses interesses empresariais, nada melhor do que se investir em um modo de ensinar e aprender que coloque cada vez mais distante as partes envolvidas nesse processo,

\begin{tabular}{|l|l|l|l|l|}
\hline Qevista Qialectus & Ano 9 & n. 19 & Agosto-Dezembro 2020 & p. 197-224 \\
\hline
\end{tabular}


estabelecendo-se e se maximizando nas relações no processo pedagógico.

Como vemos, a tecnologia parece ser mesmo uma chave que nos permite abrir as portas para grandes questões que perpassam pela formação e que, por sua vez, passam a ser de interesse do capital em suas diferentes esferas de existência. Penso, aqui, na lógica dos regimes totalitários a que serviu bem esse domínio da técnica. E isto se reflete de forma espetacular quando se tem em vista a escola onde se inserem as diferentes tecnologias com vistas a uma formação que prepare as pessoas para as demandas de mercado segundo o norte empresarial. $\mathrm{O}$ vínculo entre esse avanço das técnicas que culmina nos diferentes conglomerados tecnológicos dos nossos tempos, foi bem perceptível por, Theodor W. Adorno (2010a) ao se reportar à experiência da educação como base de efetivação de Auschwitz que se fez possível graças à coisificação da consciência. Esta, por sua vez, não teria sido possível sem o domínio necessário das técnicas para uma determinada formação. Assim torna-se impossível negar a relação entre a técnica e essa coisificação humana, onde está presente toda frieza como condição indispensável a todo o terror proporcionado pelo holocausto. Assim, compreende-se a afirmação de Adorno (2010a, p. 132): “Um mundo em que a técnica ocupa uma posição tão decisiva como acontece atualmente, gera pessoas tecnológicas, afinadas com a técnica". Observa este filósofo que não se pode ignorar a racionalidade boa que se possa encontrar nisso, quando visto "em seu plano mais restrito", porque "serão menos influenciáveis" se comparado com o que ocorre "no plano geral". Mas é preciso considerar muito mais que isso: "Por outro lado" - diz Adorno -, "na relação atual com a técnica existe algo de exagerado, irracional, patogênico. Isto se vincula ao "véu tecnológico"”. É isto que se vê, segundo ele, no inclinar-se dos homens "a considerar a técnica como sendo algo em si mesma, um fim em si mesmo, uma força própria, esquecendo que ela é a extensão do braço dos homens" (Ibidem, p. 132).

Tomando-se a técnica em si mesma, homens e mulheres esbarram em sua fetichização que, por sua vez, leva as pessoas à frieza necessária à dominação de umas em relação às outras, tornando-se, portanto, capazes das mais cruéis atrocidades. Adorno observa que, nessa fetichização, está o ponto de transição entre a racionalidade com a técnica e a sua supervalorização, o que leva, por exemplo, alguém projetar "um sistema ferroviário para conduzir as vítimas a Auschwitz com maior rapidez e fluência, a esquecer o que acontece com estas vítimas em Auschwitz" (ADORNO, 2010a, p. 133). Isto significa dizer, conforme a observação de Adorno, que a fetichização da técnica tende a transformar as pessoas incapazes de amar. Não se devendo entender isto, segundo ele "num sentido sentimental ou moralizante, mas denotando a carente relação libidinal com outras pessoas”. Seguindo com este

\begin{tabular}{|c|c|c|c|c|}
\hline Govista Dialectus & Ano 9 & n. 19 & Agosto - Dezembro 2020 & p. $197-224$ \\
\hline
\end{tabular}


entendimento, afirma que essas pessoas "são inteiramente frias e precisam negar também em seu íntimo a possibilidade do amor, recusando de antemão nas outras pessoas o seu amor antes que o mesmo se instale. A capacidade de amar, que de alguma maneira sobrevive, eles precisam aplicá-la aos meios" (Ibidem).

Essas reflexões de Adorno são importantes para o que pensamos em termos de educação quando relacionada à tecnologia, porque não podemos ignorar o que está posto e o que tanto se quer quanto se tem em vista toda demanda pelo ensino a distância, mediado pela tecnologia que o computador e a internet representam. Trata-se, pois, da frieza burguesa que se quer no processo de ensino-aprendizagem, que não surge com as novas tecnologias, portanto, não sendo oriundas do ensino a distância, mas que é própria da educação tradicional tanto contestada desde o século XVIII, com exemplo enfático em Jean-Jacques Rousseau, e que fora definida como educação bancária por Paulo Freire (1981). Se se contesta a ausência de autonomia dos alunos que, em nome de modelos a serem seguidos, são coisificados como bancos em que se deposita conhecimento, isto é, informações, avançamos para os meios que continuam colocando os alunos como receptáculos para essas informações, mesmo quando eles parecem ativos no domínio da técnica. Porém cada vez mais se distanciando da possibilidade de emancipação ao passo em que vão cada vez se confundindo com as máquinas que eles próprios utilizam para que, com elas, sejam abastecidos ou reabastecidos das informações necessárias à sua própria modelação como coisas frias para que se dê sustentação a toda frieza necessária no âmbito da exploração e da produção.

Aqui ressaltamos justamente a autonomia dos estudantes quando se pensa na qualidade da educação. Bruno Pucci (2016, p. 52), atento sobre isso, chama a atenção, dizendo se tratar de "uma questão de fundo em todo processo formativo", lembrando que isso deve ser de maior preocupação "quando esse processo se desenvolve a distância, na formação inicial de professores, em instituições de educação superior privadas", merecendo, por isso, "mais cuidado e problematização". E é este mesmo autor que, logo depois, enfatiza a questão da autonomia: "E um dos problemas que permeia os diversos tópicos de um Projeto Pedagógico de qualidade [...] é o conceito de autonomia do educando nos cursos de graduação na modalidade EaD". E ele ainda lembra das distorções que se faz em torno desse conceito: "Se esse conceito já acumula enviesada ambiguidade no ensino superior presencial, na modalidade a distância essa característica se acentua ainda mais" (Ibidem, p. 53). Confundem, portanto, criatividade e domínio técnico que o aluno pode adquirir ao fazer uso dos instrumentos eletrônicos com autonomia. Assim, quem mais domina o computador ou programas a ele

\begin{tabular}{|l|l|l|l|l|}
\hline Qenista Dialectus & Ano 9 & n. 19 & Agosto-Dezembro 2020 & p. 197-224 \\
\hline
\end{tabular}


relacionados parece ser mais autônomo, ignorando, por exemplo, o que diz Immanuel Kant (2005, p. 63) sobre a autonomia que tem por base o esclarecimento: "Esclarecimento [Aufklärung] é a saída do homem de sua menoridade, da qual ele próprio é culpado. A menoridade é a incapacidade de fazer uso de seu entendimento sem a direção de outro indivíduo" [grifos do autor]. Adorno (2010b, p. 143), retomando o pensamento de Kant, chama a atenção para o seguinte: "A educação seria impotente e ideológica se ignorasse o objetivo de adaptação e não preparasse os homens para se orientarem no mundo". Isto significa dizer, segundo ele, que "ela seria igualmente questionável se ficasse nisto, produzindo nada além de well adjusted people, pessoas bem ajustadas, em consequência do que a situação existente se impõe precisamente no que tem de pior" (ADORNO, 2010b, p. 143). Diante de tudo que fora então pensado por Kant e Adorno sobre a autonomia, faz-se, sim, necessária a questão formulada por Bruno Pucci (2016, p. 56-57):

Se o conceito de autonomia foi fundamental para Kant e para Adorno na perspectiva da constituição do indivíduo e dos grupos sociais no uso público da razão em momentos históricos diferentes, é possível resgatar a força crítica e reflexiva desse conceito em tempos de tecnologias digitais?

Podemos voltar aqui ao exposto por Natal Lânia Roque Fernandes sobre a discussão ainda embrionária a respeito da inserção das novas tecnologias na escola, envolvendo a informatização do ensino. Tomando para estudo um Curso em informática na educação para a formação de professores-multiplicadores desenvolvido pelo Núcleo de Tecnologia Educacional de João Pessoa-PB, no primeiro semestre de 2001, ela diz que esse Curso tinha como objetivo a formação de um professor crítico e participativo. E, para demonstrar isso, considerando que essa formação não deveria se limitar ao racional, mas envolver "outros elementos como o emocional, o social ou o contextual os quais estão presentes na ação de ensinar e aprender" (FERENANDES, 2004, p. 57), afirma que, no primeiro módulo, os multiplicadores, ao se voltarem para o estudo sobre a informática na educação, "escolheram como tema a reciclagem do lixo por ser, na concepção deles, um assunto amplo que pode suscitar discussões interdisciplinares e, por isso, abranger todas as disciplinas escolares" (Ibidem, p.59-60). Como, então, procederam para desenvolver a sua aprendizagem com o computador? "Antes de iniciar as atividades com o computador, foi apresentado um vídeo sobre o tema reciclagem do lixo para que os professores discutissem relacionando-o com suas disciplinas". Depois da apresentação desse vídeo como "parte introdutória", "a etapa seguinte foi realizada no

\begin{tabular}{|l|l|l|l|l|}
\hline Qevista Oialectus & Ano 9 & n. 19 & Agosto - Dezembro 2020 & p. 197-224 \\
\hline
\end{tabular}


laboratório onde os professores tiveram no curso o primeiro contato com a máquina" (Ibidem, p. 60). Isso é suficiente para dizer que, a partir da apresentação de um vídeo sobre a reciclagem do lixo haverá o despertar da consciência crítica e que isso possa ser traduzido na utilização do computador no processo ensino-aprendizagem? A separação entre a crítica que se diz querer e a formação que se busca para o aprender com as novas tecnologias fica mais evidente quando, na sequência da efetivação desse Curso, "foram introduzidos conhecimentos sobre o funcionamento da máquina, a função do estabilizador, da CPU, do monitor, do mouse, ligar e desligar". E assim, os multiplicadores puderam seguir em seu Curso aprendendo como lidar com os ícones da área de trabalho e sua movimentação, bem como com "o menu principal até chegar no Microsoft Word no qual realizaram procedimentos de digitação e formatação de textos" (Ibidem, p. 60).

Certamente trata-se aqui de um Curso que tem por fim a capacitação de professores com vistas à habilitação de professores e alunos que, posteriormente, em suas escolas, irão se deparar com a necessidade do uso do computador em suas atividades escolares, seja na condição de alunos ou de professores. Algo semelhante, porém em estágio ainda mais avançado, ocorre quando se fala, hoje, de ensino remoto ou de educação a distância online. As partes envolvidas terão que lidar com o domínio da máquina e, assim sendo, espera-se do estudante que ele seja responsável pelo seu próprio ensinar e aprender a partir do domínio adquirido das ferramentas necessárias ao processo ensino-aprendizagem que se fará pelo autodidatismo e a autodisciplina. Por isso não podemos perder de vista a questão exposta por Pucci (2016, p. 56-57):

O admirável e espantoso desenvolvimento tecnológico que invade as salas de aulas e se tornam imprescindíveis no processo formativo escolar, particularmente na modalidade a distância, não está cada vez mais debilitando o elemento espiritual e crítico do conceito de autonomia e absolutizando sua dimensão funcional, instrumental?

A resposta a esta questão parece estar nas consequências que se pode esperar desse processo de ensino e aprendizagem. O próprio Bruno Pucci chama a atenção para isso como se estivesse respondendo a sua própria pergunta. Primeiramente, como ele observa, os docentes deixam de existir: convertem-se em supervisores, estimuladores, acompanhantes ou em uma espécie de monitores ou tutores. Enquanto isso, a ênfase dada ao prefixo grego "auto" nesse processo educativo "pode ser um instrumento a mais nas mãos de uma sociedade competitiva que favorece o desenvolvimento, no interior do processo formativo, de um egocentrismo exacerbado, de uma atroz solidão e de uma identificação doentia com as máquinas inteligentes"

\begin{tabular}{|l|l|l|l|l|}
\hline Qevista Dialectus & Ano 9 & n. 19 & Agosto-Dezembro 2020 & p. $197-224$ \\
\hline
\end{tabular}


(PUCCI, 2016, p. 58-59). Isto se fará de sustentáculo para o que se pensa como frieza burguesa, ressaltada por Andreas Gruschka (2014) a partir do exposto sobre o pensamento de Adorno. Pois, segundo ele, há de se considerar o seguinte: “O discurso de que os homens se comportariam de modo frio, que seriam frios, conduz, apesar do jogo com a metáfora, a um campo de experiências e significados compreensível e socialmente distribuído de forma bem precisa" (GRUSCHKA, 2014, p. 85). Ou seja, ainda conforme suas próprias palavras: “A frieza é um conceito coletivo para diferentes formas de expressão de sentimentos sociais, que diferem em relação à atenção aos problemas sociais, à uniformidade e à sua profundidade" (Ibidem, p. 89). Ou como o diz Adorno (2010, p. 134):

\footnotetext{
Se ela $[$ a frieza $]$ não fosse um traço básico da antropologia, e, portanto, da constituição humana como ela realmente é em nossa sociedade; se as pessoas não fossem profundamente indiferentes em relação ao que acontece com todas as outras, excetuando o punhado com que mantêm vínculos estreitos e possivelmente por intermédio de alguns interesses concretos, então Auschwitz não teria sido possível, as pessoas não o teriam aceito.
}

Seguindo com esse raciocínio, Adorno enfatiza a ausência de atração e simpatia nas

relações humanas de seu tempo que, na verdade, continua sendo o nosso próprio tempo, quando nos deparamos com a ausência de amor entre as pessoas: "Em sua configuração atual - e provavelmente há milênios - a sociedade não repousa em atração, em simpatia, como se supôs ideologicamente desde Aristóteles, mas na persecução dos próprios interesses frente aos interesses dos demais" (ADORNO, 2010a, p. 134). Ou seja, nada mais se pode esperar quando se trata da coisificação humana em que a frieza toma o espaço do amor que deixa de existir entre as pessoas que não amam e não são amadas: "Hoje em dia qualquer pessoa, sem exceção, se sente mal-amada, porque cada um é deficiente na capacidade de amar", diz ele (Ibidem).

\section{A título de conclusão}

Herbert Marcuse (1999), ao se voltar para a tecnologia da sociedade industrial que surge com a modernidade, diz se tratar de um processo onde se encontra a técnica propriamente dita como aparato dessa indústria, bem como dos transportes e da comunicação. Considerada então em si mesma, há de se pensar como fator parcial de influência nos indivíduos. Pois não se pode igonrar os indivíduos que inventam a maquinaria que, de algum modo, juntam-se aos

\begin{tabular}{|c|c|c|c|c|}
\hline Qevista Dialectus & Ano 9 & n. 19 & Agosto - Dezembro 2020 & p. $197-224$ \\
\hline
\end{tabular}


gurpos sociais que direcionam a sua apliacação. Asim podemos afirmar que, segundo ele, ao tratarmos da tecnologia, precisamos considerar a influência dos grupos sociais que direcionam a aplicação da técnica no processo social. Neste sentido, a tcnologia passsa à condição de modo de produção ao tempo em que se faz como totalidade dos instrumentos, bem como dos dispositivos e invenções que "caracterizam a era da máquina, é assim, ao mesmo tempo, uma forma de organizar e perpetuar (ou modificar) as relações sociais, uma manifestação do pensamento e dos padrões de comportamento dominantes, um instrumento de controle e dominação" (MARCUSE, 1999, p. 73). E, seguindo com este raciocínio, ele também afirma: "A técnica por si só pode promover tanto o autoritarismo quanto a liberdade, tanto a escassez quanto a abundância, tanto o aumento quanto a abolição do trabalho árduo" (Ibidem, p. 74).

É partindo desse entendimento de Marcuse que procuramos pensar as novas tecnologias disponíveis para o ensino remoto como base para uma nova forma de educação tradicional. Pensamos que a crítica iluminista, ou mais propriamente a contestação de Rousseau no Emílio, possa ser referência para o desdobramento dado pela Nova Escola ao que fora proposto como educação conforme a natureza. Dizia Rousseau que, em sua época (século XVIII), já não se podia falar de escola pública. Tratava-se de uma escola que não formava nem o homem nem o cidadão, quando não seria possível formá-los ao mesmo tempo. A educação negativa que teria que tomar o lugar dessa escola positivada esbarrou no espontaneismo do escolanovismo, permitindo-se falar da desescolarização da sociedade bem como da instrumentalização da escola oferecida pelo aparato da técnica que acaba encaminhando tudo para a padronização. Com vistas a esta padronização, situamos agora a formação a que se pode chegar pela via da escolaridade no limiar da robotização do humano. Nesses termos, professores, agora padronizados, isto é, reduzidos a uma pura extensão da máquina, fazem-se, na condição de monitores, encarregados da promoção da sua correspondente padronização conforme o aparato, isto é, segundo a inserção da tecnologia na escola.

Com essa nova forma de se pensar a escola, já não se pode acreditar como coisa do passado o que fora denunciado por Paulo Freire na Pedagogia do oprimido: de um lado, a "narração ou dissertação" implicando um sujeito; do outro lado, os educandos como "objetos pacientes", isto é, meros ouvintes. Certamente temos agora os educandos que operam a máquina, que se autodisciplinam segundo as condições que lhes são dadas pela tecnologia. Mas como se dá a sua autonomia em relação ao conteúdo? Reduz-se ao domínio técnico com que operam a máquina, distanciando-se das possibilidades de interação humana com que poderia se fazer, também, como sujeitos, isto é, como quem pode também dissertar. Mas não há espaço

\begin{tabular}{|l|l|l|l|l|}
\hline Qenista Dialectus & Ano 9 & n. 19 & Agosto-Dezembro 2020 & p. 197-224 \\
\hline
\end{tabular}


para isso numa sociedade em que homens e mulheres aprendem a ser obedientes às instruções ao manipularem a máquina para obterem resultados desejados. Ou seja, onde não há espaço para a autonomia. Assim, segundo Marcuse, a adaptação ao aparato passou a ser sinônimo de sucesso, ao tempo que a racionalidade individualista se transformou "em eficiente submissão à seqüência predeterminada de meios e finns". Enquanto isso, esta sequência "absorve os esforços libertadores do pensamento" ao passo em que "as várias funções da razão convergem para a manutenção incondicional do aparato" (MARCUSE, 1999, p. 80). E isso vai se consolidando à medida em que se propaga a "mecânica da submissão", indo "da ordem tecnológica para a ordem social; ela governa o desempenho não apenas nas fábricas e lojas, mas também nos escritórios, escolas, juntas legislativas e, finalmente, na esfera do descanso e lazer" (Ibidem, p. $82)$.

A falsa autonomia que parece estar com o educando, dando inclusive o indicativo de que já não há mais lugar para o professor no processo ensino-aprendizagem, esconde esse "pacto" que acaba se firmando entre educandos e às tecnologias com que eles vão se adaptando, ao ponto de se tornarem verdadeiros autômatos. E, diga-se aqui, tecnologias, e não tecnologia, por se saber da significação do aparato que abrange os meios de comunicação de massa perpassando por toda mídia com que se encantam professores e alunos, rendendo-se à racionalidade técnica. As diferentes ferramentas com que se opera o ensino, dispostas em eficazes plataformas, parecem encurtarem o caminho em direção à aquisição do conhecimento. Parece que já não se confere mais "largos poderes de iniciativa" ao mestre, como ocorria entre os jesuítas, conforme nos diz Leonel Franca S. J. (1952). Ou, como diz ainda esse mesmo autor, a Ratio orientava no sentido de que o aluno exercitasse, "não tanto a memória, mas também e principalmente a imaginação, o juízo e a razão" (Ibidem, p. 57). Não se trata mais de se enfatizar a influência dos antigos ou de se colocar os grandes exemplos da filosofia, das ciências, letras e artes como modelos a serem seguidos. Porém, têm alunos e professor, diante de si, a máquina com que interagem, de forma fria, como se tivessem interagindo consigo mesmos ou com imagens e vozes de um mundo reduzido a máquinas e programas com que todos lidam para que a comunicação se faça possível. E, com isso, o professor parece já não ser fundamental no processo ensino-aprendizagem, porque a tecnologia tornou-se agora a condição de ser do sucesso a que se se chega pela padronização de comportamento requerido pelos que inventam as máquinas e, de longe, manipulam o conhecimento para que este seja, de fato, eficaz aos seus próprios interesses. Enquanto isso, os alunos continuam acumulando informações de que se valem para lidarem com a máquina e serem bem-sucedidos quando expõem essas mesmas

\begin{tabular}{|l|l|l|l|l|}
\hline Q Revista Dialectus & Ano 9 & n. 19 & Agosto-Dezembro 2020 & p. 197-224 \\
\hline
\end{tabular}


formações no domínio das técnicas, indispensáveis ao modo de produção e de consumo. Afinal, para que o capitalismo tenha continuidade, e possa se fortalecer, é preciso que as pessoas e as máquinas pareçam se confundir, à proporção em que se façam como meio para o aumento cada vez maior de lucro das empresas, isto é, dos que têm a posse e controle dos meios de produção, e o processo tecnológico se firma como base para isso, quando absorve professores e alunos, no âmbito do ensino e da aprendizagem, fazendo-se, portanto, escola. Assim sendo, a educação e a tecnologia encontram-se imbricadas quando o ensino se reafirma em seu modo mais tradicional de ser, apesar do seu novo formato, graças às tecnologias que vão se renovando segundo as demandas das inovações capitalistas.

\section{Referências:}

ADORNO, Theodor W. Educação após auschwitz. In: ADORNO, Theodor W. Educação e emancipação. Tradução por Wolfgang Leo Maar. 5. Reimpressão. Rio de Janeiro: Paz e Terra, 2010a.

Educação - para quê? In: ADORNO, Theodor W. Educação e emancipação. Tradução por Wolfgang Leo Maar. 5. Reimpressão. Rio de Janeiro: Paz e Terra, 2010b.

Teoria da semiformação. Tradução Newton Ramos-de-Oliveira. In: PUCCI, Bruno; ZUIN, Antônio A. S.; LASTÓRIA, Calmon Nabuco (Orgs.). Teoria Crítica e inconformismo: nova perspectivas de pesquisa. Campinas-SP: Autores Associados, 2010c. p. $7-40$.

ALVITE, Maria Mercedes Capelo. Didática e psicologia: crítica ao psicologismo na Educação. São Paulo: Loyola, 1981. 136 p. (Coleção "EDUCAÇÃO”; 2).

ARANHA, Maria Lúcia de Arruda. Filosofia da educação. 3. ed. Rev. Amp. São Paulo: Moderna, 2010. 228 p.

CAMBI, Franco. História da pedagogia. Tradução por Álvaro Lorencini. São Paulo: UNESP, 1999. 704 p. Tradução de: Storia della pedagogia.

COMÉNIO, João Amós. Didáctica magna: tratado da arte universal de ensinar tudo a todos. Tradução por Joaquim Ferreira Gomes. 3. ed. Lisboa : Fundação Calouste Gulbenkian, 1985. 530 p. (Textos Clássicos). Tradução de: Didáctica Magna.

FERNANDES, Natal Lânia Roque. Professores e computadores: navegar é preciso! Porto Alegre: Mediação, 2004.

FRANCA S. J, Leonel. O método pedagógico dos jesuítas: O "Ratio Studiorum". Rio de Janeiro: Agir, 1952.

FREIRE, Paulo. Pedagogia do oprimido. 10. ed. Rio de Janeiro: Paz e Terra, 1981.

\begin{tabular}{|l|c|c|c|c|}
\hline Qevista Dialectus & Ano 9 & n. 19 & Agosto-Dezembro 2020 & p. $197-224$ \\
\hline
\end{tabular}


GRUSCHKA, Andreas. Frieza burguesa e educação: a frieza como mal-estar da cultura burguesa na educação. Campinas-S: Autores Associados, 2014. (Coleção Educação Contemporânea).

KANT, Immanuel. Resposta à pergunta: Que é “esclarecimento"? (Aufklärung) (5 de dezembro de 1783). Textos seletos. Tradução Floriano de Sousa Fernandes. 3. ed. Petrópolis-RJ: Vozes, 2005. (Coleção Textos Filosóficos).

LIBÂNEO, José Carlos. Democratização da escola pública; a pedagogia crítico-social dos conteúdos. 8. ed. São Paulo: Loyola, 1989. 152 p. (Coleção Educar, 1).

MANACORDA, Mario Alighiero. História da educação: da Antigüidade aos nossos dias. Tradução por Gaetano lo monaco. 8. ed. São Paulo: Cortez, 2000. 382 p. Tradução de: Storia dell'Educazione: dall'antichità a oggi.

MARCUSE, Herbert. A ideologia da sociedade industrial. Tradução por Giasone Rebuá. 6. ed. Rio de Janeiro: Zahar, 1982. 240 p. (Atualidade). Tradução de: One-Dimensional Man Studies in the Ideology of Advanced Industrial Society.

Tecnologia, guerra e fascismo. Tradução Maria Cristina Vidal Borba. São Paulo: UNESP, 1999. 376 p. (Biblioteca básica). Tradução de: Technologuy, War and Fascism.

MIZUKAMI, Maria da Graça Nicoletti. Ensino: as abordagens do processo. São Paulo: EPU, 1986. (Temas básicos de educação e ensio).

NOT, L. As pedagogias do conhecimento. Tradução de Américo E. Bandeira. ed. São Paulo: DIFEL, 1981.

PUCCI, Bruno. A questão da autonomia dos estudantes nos cursos de formação inicial de docentes da educação básica a distância online. In: PUCCI, Bruno... [et. Al] (Orgs.). Atualidade da teoria critica na era global. São Paulo: Nankim, 2016. p. 52-67. (Coleção Teoria Crítica; 4).

ROUSSEAU, Jean-Jacques. Discurso sobre as ciências e as artes. Tradução por Lourdes Santos Machado. São Paulo: Nova Cultural, 1999. p.165-214. (Coleção Os Pensadores Rousseau, vol. II).

Emílio ou da educação. Tradução por Sérgio Milliet. 3. ed. Rio de Janeiro: Bertrand Brasil, 1995. 592 p.

SAVIANI, Demerval. Escola e democracia: teorias da educação, curvatura da vara, onze teses sobre educação e política! 32. ed. Campinas, SP: Autores Associados, 1999. (Coleção polêmicas do nosso tempo; v. 5).

SNYDERS, Georges. Pedagogia progressista. Coimbra: Livraria Almedina, 1974.

\begin{tabular}{|l|l|l|l|l|}
\hline Qevista Dialectus & Ano 9 & n. 19 & Agosto-Dezembro 2020 & p. 197-224 \\
\hline
\end{tabular}

